\title{
SiM
}

\section{Sponsored Issue Acknowledgments}

The guest editors and authors thank the sponsors who made this issue possible. The issue originated in the Strategic Grazing Management for Complex Adaptive Systems symposium hosted by the Colorado Section Society for Range Management at Colorado State University in November 2012, sponsored by the Colorado Grazing Lands Conservation Initiative and supported by the Society for Range Management (for abstracts and presentations, see http://rangelands.org/strategicgrazing). Publication was further sponsored by the Texas Grazing Lands Conservation Initiative and the Caesar Kleburg Wildlife Research Institute.

Colorado Section Societyfor Range Management

The Society for Range Management and the Colorado Section SRM are a well-trained and highly motivated group of professionals and rangeland users working with productive, sustainable rangeland ecosystems. SRM is the professional society dedicated to supporting persons who work with rangelands and have a commitment to their sustainable use. SRM is dedicated to the conservation and sustainable management of rangelands for the benefit of current societies and for future generations. For more information, see http://cssrm.org and https://www. facebook.com/COSocietyforRangeManagement.

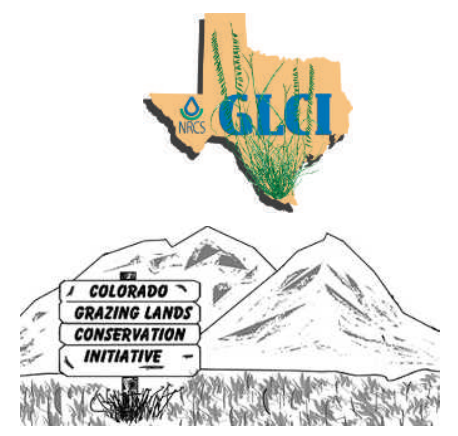

The Grazing Lands Conservation Initiative was founded to provide high quality technical assistance on privately owned grazing lands on a voluntary basis and to increase the awareness of the importance of grazing land resources. Established in 1991, GLCI is carried out through coalitions of individuals and organizations functioning at the local, state, regional and national levels. The coalitions include livestock producer organizations, scientific and professional grazing resource organizations, conservation and environmental groups, and state and federal natural resource and agriculture agencies. For more information, see http://www.glci. org and https://www.facebook.com/texasglci.

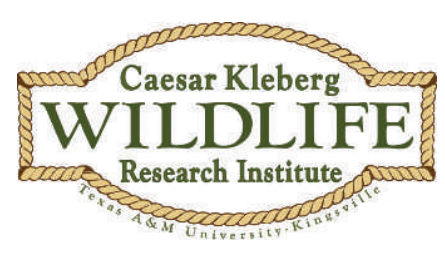

The Caesar Kleberg Wildlife Research Institute at Texas A\&M University-Kingsville is the leading wildlife research organization in Texas and one of the finest in the nation. Its mission is to provide science-based information for enhancing the conservation and management of wildlife in South Texas and related environments. For more information, see http://www. ckwri.tamuk.edu and https://www.facebook.com/pages/Caesar-Kleberg-Wildlife-ResearchInstitute/105131706212701. 